\title{
Legal Review Doctor's Professional Liability Insurance To Patients
}

\author{
Febrina Lorence Sitepu
}

North Sumatera University Faculty Of Law. E-mail: febrina65@gmail.com

\begin{abstract}
ARTICLE INFO
Keywords:

Legal Review, Doctors

Profesional Liability

Insurance, Patient

Article history:

Received Sept 29, 2019;

Revised Oct 20, 2019;

Accepted 01 Jan, 2020;

Online Jan 30, 2020.

ABSTRACT

The cause of disputes that occur between patients and doctors is often due to an alleged medical malpractice carried out by doctors in carrying out their duties as providers of health services to patients, and resulting in losses for patients. Through professional liability insurance, doctors can transfer all risks of a patient's lawsuit against him to the insurer by paying a certain premium, and the insurer provides compensation to the patient who filed the lawsuit. As for the problem in this thesis is how the professional obligations of doctors in providing services to patients and the possibility of malpractice as the basis for the existence of medical professional liability insurance, The research method used in the preparation of this thesis is the normative juridical method. The normative juridical research method is used in this study to conduct searches on legal norms, as well as to obtain data and information contained in various literatures in libraries, research journals, newspapers, magazines, internet sites and so on. Doctors' professional obligations in providing services to patients are regulated in the Indonesian Medical Code of Ethics (KODEKI) and Law No. 29 of 2004 concerning Medical Practice. Broadly speaking, the doctor's professional obligations to the patient are: protecting the life of human beings, being sincere and using all their knowledge and skills for the benefit of the patient, keeping everything he knows about a patient even after the patient dies, performing emergency assistance as a duty. humanity, as well as increase knowledge and follow the development of medical science or dentistry. Medical malpractice is a doctor's behavior that is not right, which violates morals and laws. This malpractice occurs due to negligence in carrying out the practice of the medical profession. Legal liability insurance arises in connection with legal aspects in society where it is possible to sue other parties as individuals or business entities for careless actions or negligence. Arrangements for legal relations between doctors and insurance companies are specifically regulated in insurance policies. The policy is used as evidence that there has been an insurance agreement between the insurer (insurance company) and the insured (doctor). In addition, the regulation of legal relations between doctors and insurance companies is also regulated in the Commercial Code, the Civil Code, and Law no. 23 of 1992. The forms of risk that can be transferred by the doctor as the insured with the insurance company as the insurer are: bodily injury to the patient caused by the actions of the insured that occur in the area of coverage during the validity of the policy, actions taken by authorized health workers who are not doctors or doctors teeth that help the insured, events that result in loss and claims from patients, professional liability insurance only applies to compensation for losses that are determined to be located in the country of address of the insured party. So there are several ways to settle disputes over these claims, namely: through peaceful means, through arbitration institutions, through court processes. bodily injury to the patient caused by the actions of the insured that occurred in the coverage area during the validity of the policy, actions taken by authorized health workers
\end{abstract}




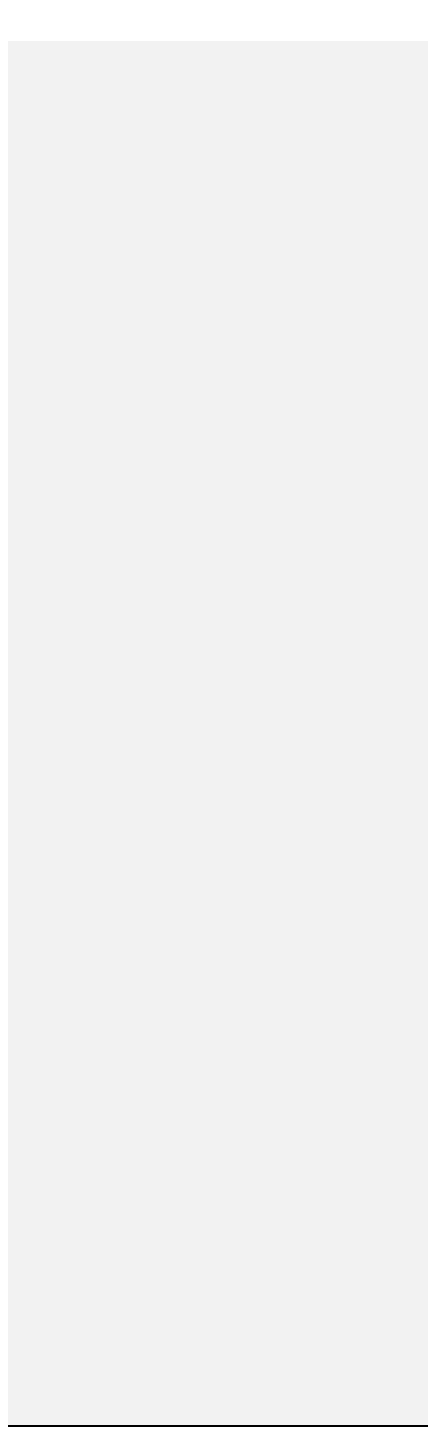

who were not doctors or dentists who assisted the insured, events that resulted in losses and claims from patients, liability insurance the medical profession only applies to compensation for losses that are determined to be located in the country of address of the insured party. So there are several ways to settle disputes over these claims, namely: through peaceful means, through arbitration institutions, through court processes. bodily injury to the patient caused by the actions of the insured that occurred in the coverage area during the validity of the policy, actions taken by authorized health workers who were not doctors or dentists who assisted the insured, events that resulted in losses and claims from patients, liability insurance the medical profession only applies to compensation for losses that are determined to be located in the country of address of the insured party. So there are several ways to settle disputes over these claims, namely: through peaceful means, through arbitration institutions, through court processes. events that result in losses and claims from patients, medical professional liability insurance only applies to compensation for losses that are determined to be located in the country of address of the insured party. So there are several ways to settle disputes over these claims, namely: through peaceful means, through arbitration institutions, through court processes. events that result in losses and claims from patients, medical professional liability insurance only applies to compensation for losses that are determined to be located in the country of address of the insured party. So there are several ways to settle disputes over these claims, namely: through peaceful means, through arbitration institutions, through court processes. Based on these explanations and conclusions, the author suggests that professionals should take professional legal liability insurance, especially for doctors to take medical professional liability insurance. It is recommended that efforts to introduce medical professional liability insurance products be increased to protect patients and doctors in the event of medical malpractice. The amount of premium should be adjusted to the condition of doctors and patients in Indonesia. In accordance with the development and progress of the medical profession, the Government should immediately stipulate a provision regarding the medical professional standard.

This is an open access article under the CC BY-NC license.

\section{Introduction}

Every human being has various needs in his life, which are divided into primary, secondary, and tertiary needs. Heal this one of the most important needs in human life, because health is a state that is coveted by everyone. To maintain health, everyone will consume nutritious food, exercise moderately, and so on.

The problem will be different when someone falls ill who needs the help of others. However, health is a basic need in life, while the knowledge and skills of each patient is different. Thus, patients and their families will seek help from health workers. Because of this, it takes a professional in the health or medical field who we know as a doctor. The medical profession is one of the professions that in carrying out their duties must first have higher medical education, expertise and skills in their field, therefore doctors are commonly referred to as professionals.

Patients should be seen as subjects who have a "big influence" on the final service outcome, not just an object. Patients' rights must be fulfilled considering that the patient's needs are one of the barometers of service quality, otherwise patient dissatisfaction will lead to a lawsuit. As consumers of the services provided by someone, the patient certainly has expectations of the health service provider, which consists of reliability (reliability), responsiveness (responsiveness), assurance (guarantee), and empathy (empathy). Nowadays, people are increasingly aware of their rights as health consumers. They often critically ask about the disease, examination, treatment, and actions to be taken regarding the disease. Not infrequently 
they seek a second opinion (second opinion). This is a right that deserves to be respected by health service providers. It must be admitted that the rights of patients as consumers of health services are still often defeated by the power of the health service providers themselves, and the patient's knowledge about health is very limited. The impact of this is felt by patients as consumers of health services, and it often causes enormous losses for patients, both moral and material losses.

As a result of the interaction between patients as consumers and providers of health services, there will be a legal relationship between the patient and the health care provider, which will give birth to the rights and obligations of the parties. As a consequence of the implementation of these rights and obligations, a dispute often arises because one party feels aggrieved, in practice it is often the patient who feels aggrieved.

The types of consumer protection problems since the enactment of Law no. 8 of 1999 concerning consumer protection is diverse, but consumer claims against health services and related health problems are still relatively rare. The cause of disputes that occur between patients and doctors is often due to an alleged medical malpractice carried out by doctors in carrying out their duties as providers of health services to patients and resulting in losses for patients. Juridically, all suspected malpractice cases can be submitted to criminal or civil courts for proof based on medical standards. If a doctor is proven not to deviate from the standard of the medical profession, he is not sentenced or decided to be free to pay damages. An example of a malpractice case carried out by a doctor is against the wife of lawyer Hotman Paris Hutapea. Where the doctor from Mitra Kemayoran Hospital said that the uterus of Hotman Paris Hutapea's wife was infected and had precancerous symptoms (Cin II- in her womb).

According to the doctor who was at Mitra Kemayoran Hospital, the uterus of the lawyer's wife had to be removed including removing the inside third of the vagina. Before performing the removal of the uterus, doctors from the hospital gave injections of antibiotics to clear the infection at a dose of three times a day for seven days, each at 1,500 milligrams per day. But after four days later the wife of the lawyer became vomiting almost once every five minutes and continued a week later.

Finally, the lawyer's wife was taken to MMC Hospital, Kuningan, and from there it was discovered that the lawyer's wife's kidney function had decreased to 18 percent and her blood creatine level was close to seven even though her normal creatine level was around 1.2. Dissatisfied with the doctor's examination, the lawyer took his wife to Mount Elizabeth Hospital, Singapore. After an examination at the hospital, the doctor from the hospital stated: His wife's decreased kidney function was caused by the use of high doses of the antibiotic ciprofloxacin.

Apart from the above cases, there is also a malpractice case that happened to Irwanto, a lecturer at Atma Jaya Catholic University. Where the doctor from the Bintaro International Hospital (RSIB) explained that the front left upper heart chamber was blocked and he had to be infused with streptokinase as much as Rp. 1.5 million international units (IU) for Rp. 4.8 million per infusion. Three hours later, Irwanto was scanned that same night at Gleneagles Hospital, Karawaci, Tangerang. Then the cardiologist, neurologist and neurosurgeon concluded that there was pressure in the spine (spinal infarct), at the C3-C4 section, around the nape of the neck. According to the doctors, it happened because there was blood or flesh of the tumor, then Irwanto was advised to undergo surgery immediately.

The changing conclusions of the doctors prompted the family to seek a second opinion from Padmosantjojo, professor of neurosurgery at the Faculty of Medicine, University of Indonesia. After seeing the results of the MRI (Magnetic Resonance Imaging), the professor suggested canceling the operation. However, Irwanto continued to be given 
Lovenox's heart medication. Two days later, the doctor asked the family to buy Aggrastat which is also a heart medicine. Where the function of Aggrastaat is almost the same as Sreptokinase, namely to prevent blood clots at a price of around Rp. 7 million.

The doctor's responsibility arises when there is a lawsuit filed by the patient against the doctor to claim compensation for an negligence by the doctor in carrying out his obligations that are not in accordance with medical professional standards, causing harm and violating the patient's rights. To relieve the responsibility of the doctor in relation to the risks he carries and carrying out his professional duties, it can be done by transferring the risk to another party. Such an agreement is referred to as an insurance agreement for coverage.11 The insurance company or the insurer provides professional liability insurance for the doctor, in which the doctor can transfer all risks of a patient's lawsuit against him to the insurer by paying a certain premium. the lawsuit (if found guilty by the judge).

The object of insurance in the medical profession liability insurance is included in the object of insurance without objects. The object of medical professional liability insurance is the obligation to pay compensation to patients arising from the negligence or error of the doctor in carrying out his duties.

\section{Method}

The Research method used in the preparation of this thesis is the normative juridical method. The normative juridical research method is used in this study to conduct searches on legal norms, as well as to obtain data and information contained in various literatures in libraries, research journals, newspapers, magazines, internet sites and so on.

The data in this study were collected through library research to obtain primary legal materials, secondary legal materials, and tertiary legal materials.

Primary legal materials can be in the form of Laws, Government Regulations, and Regulations of the Minister of Health. Secondary legal materials can be in the form of scientific works in the form of expert opinions, either in the form of books, papers, articles, other scientific works or writings on the internet. Tertiary legal materials, consisting of materials that provide instructions and explanations of primary and secondary legal materials, such as dictionaries and legal encyclopedias.

\section{Analysis and Results}

\subsection{Claim Submission}

\section{a. Claim Submission Process}

Doctor who buys a doctor's professional liability insurance policy, if he faces a lawsuit and the patient is a third party, then because he is the insured and the insurance company is the insurer, the doctor can transfer all risks of the emergence of a claim from the third party to the insurance company, as long as the claim occurs during the period of coverage. The doctor's activity of transferring all risks from the emergence of a claim from the third party to the insurance company is called a claim.

A claim is "a claim for a right, which arises because the conditions in a pre-determined agreement have been fulfilled. Life Insurance Claim is "a claim from the policy holder/appointed to the Insurance party, for a sum of Sum Assured (UP) or Cash Value payments that arise because the conditions in the insurance agreement have been fulfilled. 
The doctor's activity of transferring all risks from the emergence of a claim from the third party to the insurance company is called a claim.

Domiciled as the insured and the insurance company is domiciled as the insurer, the doctor can transfer all risks arising from claims from the third party to the insurance company, as long as the claim occurs during the period of coverage.

The causes of claims on insurance are:

1) Insured dies

2) The policyholder stops paying the premium and decides the insurance agreement when the policy has a cash value.

3) The insurance agreement has ended in accordance with the period stated in the policy and the obligations of the policyholder have been fulfilled or the policy is in a state of lapse but has a cash value (expired premium-free contract).

4) The insured got into an accident.

5) The insured due to an illness needs to be hospitalized or outpatient.

Medical professional liability insurance at an insurance company, only applies if the event of a loss arises and a claim from the patient is made in writing to the insured or the insurer during the validity period of the policy. The procedure that must be carried out by a doctor in submitting a claim is as follows:

1) If the insurance participant doctor suspects that there will be a lawsuit from the patient against him. The doctor must notify the insurance company. The notice is accompanied by information about the doctor's professional liability insurance policy number, and the notice must include:

a) Background and chronology of events which includes a description of the patient's condition and time to time, diagnosis, medical action, and details of the events that are the problem;

b) Potential injuries and the names and addresses of the persons involved in the incident; including people who are potential claimants;

c) How the insured party became aware of the incident;

d) Why the insured party expects that there will be a claim from him.

Then the medicolegal team from the insurance company, which consists of experts in the medical code of ethics, will provide tips to the doctor in taking an action that can prevent the patient from filing a lawsuit.

2) If there is a demand and the patient to the doctor. The claim submission process can be carried out by a doctor participating in the medical professional liability insurance by giving written notification to the claims section of the insurance company by preparing the following documents:

a) Photocopy of the Indonesian Doctors Association (IDI) Membership Card and the relevant Specialist Doctors Association Member Card;

b) Photocopy of Practice License and Practice Place Approval Letter that is still valid (or STR and SIP after the Medical Practice Law comes into effect);

c) Photocopy of professional insurance policy;

d) Documents or chronological minutes of monitoring the continuation of claims or lawsuits, for example: the arrival of the patient's family, the patient's lawyer, and others.

If the written claim letter from the patient has been received by the doctor, the doctor must attach the claim letter to the company using a special form for that. 


\section{b. Examination Of Claims Submitted}

If all the requirements have been met, then the insurer conducts an examination for proof, namely checking the correctness of all requirements or other matters relating to the emergence of a claim. Regarding the notification made by the insurance participant doctor, immediately follow up with :

1) Examine the administrative validity of a doctor's membership in the shortest possible time.

2) Visit the doctor, or call, or send an email/letter to the doctor, to:

a) Provide information about the general attitude that should be taken in dealing with the problem;

b) Request completeness of documents; insurance company

c) Confirm the patient's demands (if any) and the doctor's needs.

3) Contact the insurance company's medicolegal team, by providing all the information. The insurance company's Medicolegal team will follow up with:

a) Briefly assess the position case in terms of medical law;

b) Confront or dialogue with doctors to get a more complete picture and provide consultation and tips on certain attitudes that must be taken;

c) Take charge of dealing with the press and patient lawyers, if necessary in cooperation with IDI/PDGI/PDSp.

Each insurance company must establish a standard procedure for processing claims. This standard procedure is designed to strike a balance between the right of the beneficiary to obtain coverage immediately and the insurer's need to check the validity of the claim. The claim examination process begins when the claimant notifies the insurance company that the insured has died. Usually the person who makes a life insurance claim is the main heir.

After being notified of the death of the insured, the insurance company will provide the claimant with a claim form to fill out. The claimant must provide evidence to the insurer that the insured on the policy has died. Usually the included document is a death certificate. After all the required documents are included then the claim will be processed by the insurance.

The claims examination process The employees of the insurance company who are responsible for the examination process are usually called claims examiners, claims analysts. In the process and payment of claims, the claim examiner will:

1) Determine the status of the policy.

2) Verify the insured's data.

3) Checking death with insured point of death.

4) Check the amount of loss borne by the policy.

5) Determine who should receive the sum insured.

6) Determine the amount of coverage to be paid.

\subsection{Implementation Of Claim Settlement}

\section{a. Claim Settlement}

After the claim has been analyzed and investigated by the insurer and has received approval from the insurer that the claim does not have elements that can cancel it, then the next stage is the implementation of claim settlement.

At the insurance company, after the insurance participant doctor fulfills the requirements in the claim submission process, as soon as possible a settlement process will be carried out on the claims submitted by the patient by bringing together the parties concerned, namely:

1) Doctor

At the meeting between the doctor and the patient to settle the lawsuit, the doctor will be accompanied by the medicolegal team of the insurance company, and the director of the hospital where the doctor practices that caused the lawsuit and the patient. 
2) Patient

The meeting held between the patient and the doctor will determine the settlement of the patient's demands, which can be done in two ways, namely:

a) Peaceful Way

Settlement of claims through peaceful means, namely settlement through deliberation or negotiation.

Deliberations or negotiations are carried out on the principle of kinship, to make an agreement on the amount of reimbursement of claims to patients, and not to settle claims through the courts. In insurance companies, the settlement of claims is always sought through peaceful means. The role of the medicolegal team in the settlement of claims through peaceful means is very large, because one of the tasks of the medicolegal team is to try their best so that the settlement process is carried out by peaceful means.165

b) Through Court Process

If an amicable agreement or deliberation is not reached, then the claim will be settled through a decision and a court, where a third party files a claim against the insured (the insured/doctor as the defendant and the third party/patient as the plaintiff). In the case of settlement of cases in court, the insurer will bear the costs of the dispute resolution process, and provide a lawyer, whose services will be used to defend the insured (doctor). In insurance companies, the settlement of claims is always sought through peaceful means. So far, none of the claims made by insurance companies have been resolved through a court process.

In other words, all claims are settled through peaceful means because the settlement process through the court process has various shortcomings :

1) Requires a large fee, because it includes court fees and attorney's defense fees.

2) Through a convoluted trial procedure.

3) The trial process takes a relatively long time.

4) The good name of the doctor (the insured) can be tarnished, because even though there is a presumption of innocence, in society there is a bad assumption that if a problem occurs until the trial shirt, then the public's trust in the doctor will decrease and it will be very detrimental to the doctor.

\subsection{Claim Payment}

After an agreement is reached between the two parties regarding the amount of compensation payment, the insurer must immediately carry out his obligation to pay the compensation to the insured which will be immediately handed over to a third party. By making a payment to a third party, the claim against the insured will automatically be deleted, unless there is still a lack of payment.

The provisions of Article 246 of the KUHD state: "the insurer must pay compensation when an unspecified event occurs.

Based on the insurance agreement, the insurer is obliged to pay compensation. Insurers at the Indonesian Doctors Association Professional Insurance guarantee the payment of compensation for malpractice actions taken by the insured in carrying out his profession.

The insured (doctor) who receives a claim or claim for compensation from a third party must immediately report to the insurance claims section of the Indonesian Doctors Association about the existence of such malpractice claims or claims against him.

In getting compensation for losses, the amount is based on the limit of coverage stated on the policy. The Insured bears the risk of each claim of Rp. 500.000,00 (five hundred thousand rupiah) and the insurer will pay the claim to the insured if the amount of compensation 
demanded exceeds Rp. 500,000.00 (five hundred thousand rupiah) as the insured's own risk. The aggregate limit for each insurance period is the maximum amount of compensation that can be paid by the insurer during the insurance period. This means that no matter how many times the insured makes a claim to the insurer during the period of coverage, the accumulated amount must not exceed the aggregate limit, if it exceeds the aggregate limit, the doctor is responsible for paying the excess and the aggregate limit for compensation.

Based on the insurance company's professional liability insurance policy, that if there is a doctor participating in the insurance/insured who pays a claim without the approval of the insurance company/insurer, then the payment fee is not the responsibility of the insurer, and is the responsibility of the doctor himself, because the doctor violates procedures for resolving claims. However, from experience, if this happens, the insurer does not simply release his responsibility, even though he has the right to do so, but gives ex gracia, or money as a sign of sympathy for the doctor, equal to half of the costs incurred by the insured to pay compensation to the patient. 170 This is done by the insurer, because the insurer wants to build partnerships and togetherness with doctors,

\section{Conclusion}

A dispute resolution system that is as simple, fast and low-cost, is one of the principles in the judiciary in Indonesia, as stipulated in Article 4 paragraph (20) Judicial Powers. Such a settlement system is very much needed in the business world, including in consumer dispute resolution.

Although theoretically, the needs of the business world have been regulated in legislation, but the implementation is not as expected. Because in the judicial process there are still other processes that directly contradict the simple, fast and low cost principle, namely the availability of legal remedies against every decision, whether they are ordinary legal remedies or extraordinary legal remedies.

The availability of legal remedies against decisions, whether they are ordinary legal remedies or extraordinary legal remedies, will naturally prolong the dispute resolution process, so that dispute resolution will take a long time and be expensive. The high cost of the case is not the only weakness of dispute resolution through the courts today, because as already mentioned that dispute resolution through the courts is generally criticized, not only in developing countries such as Indonesia, but also in developed countries.

\section{References}

Ameln, Fred, Capita Selecta Health Law, Graphicatama Jaya, Jakarta, 1991. Paragraph, Safri, Practical Insurance Dictionary, Erlangga, Jakarta, 1996.

Bertens, K, Ethics, Gramedia Pustaka Utama, Jakarta, 1997.

Darmawi, Herman, Insurance Management, PT. Earth Literacy, Jakarta, 2004. Dojodirdjo, Mugni, deed Oppose Law, Pradnya paramitha, Jakarta, 1979.

Hanafiah, Muhammad Jusuf and Amri Amir, Medical Ethics and Health Law, Medical Book Publisher, Medan , 1999.

Harsono, Sonni Dwi, Insurance Economics, Faculty of Economics, University of Indonesia, Jakarta, 1996.

Hartono, Sunaryati, Legal Research in Indonesia, Alumni, Bandung, 1994.

Hartono, Sri Fortune, Insurance Law and Insurance Companies, Sinar Graphic, Jakarta, 2001. 
Hornby, AS (ed.), Oxford Advance Learner's Dictionary of Current English 5th, Oxford University, New York, 1995.

Karbala, Husein, Ethical and Juridical Aspects of Informed Consent, Sinar Harapan Library, Jakarta, 1993.

Koehn, Daryln, Foundations of Professional Ethics, Kanisius, Yogyakarta, 2000.

Lebo, Jef, Anthology of Law and the Medical Profession in Indonesian Society, Liberty, Yogyakarta, 1985.

Medicolegal, Consultant, Medicolegal Aspects of Medical Practice, Jakarta.

Miru, AhmadiandSutarman Yodo, Consumer Protection Law,PT. Raja GrafindoPersada, Jakarta, 2007.

Nasution, Bahder Johan, Doctor's Liability Health Law,PT. Rineka Cipta, Jakarta, 2005.

Prakoso, Djoko, Insurance in Indonesia, Dahara Prize, Semarang, 1991. Prodjokoro, Wirjono, Insurance Law in Indonesia, Intermasa, Jakarta, 1991.

Purba, Radiks, Understanding Insurance in Indonesia, Pustaka Binaman Pressindo, Jakarta, 1992.

Purwosutjipto, HMN, Basic Understanding of Indonesian Commercial Law, Djambatan, Jakarta, 1990.

Salim, A.Abbas, Insurance Fundamentals, PT. Raja Grafindo Persada, Jakarta, 2001.

Shofie, Yusuf, Consumer Dispute Resolution, PT. Citra Aditya Bakti, Yogyakarta, 2003.

Simanjuntak, Pangaribuan Emmy, Insurance Law, Section of Commercial Law, Faculty of Law, GajahMada University, Yogyakarta, 1990.

Soekanto, Soerjono and Herkutanto, Introduction to Health Law, Youth Work, Bandung, 1987.

Sumaryono, E, Ethics of the Legal Profession, Kanisius, Yogyakarta, 1995. Suseno, F. Magic, Social Ethics, Gramedia Pustaka Utama, Jakarta, 1999.

Commercial Law Code. Code of Civil law. Indonesian Medical Code of Ethics (KODEKI Government Regulation No. 36 of 1999 concerning Applications Permission Medical.

Government Regulation No. 63 of 1999 concerning the Operation of Insurance Companies and Reinsurance Companies.

Law Number 1419 of 2005 concerning the Practice of Doctors and Dentists.

Law Number 23 of 1992 concerning Health.

Law Number 8 of 1999 concerning Consumer Protection. Law Number 2 of 1992 concerning Insurance.

Law Number 30 of 1999 concerning Alternative Arbitration for Dispute Resolution.

Tempo News Room, March 28, 2004.

http:// www.Cybermed. Cbn. Net. ID/details. Asp/category=consumer and News no=140.htm. 